\title{
Screening of problems related to alcohol, tobacco and cannabis in primary care settings: a comparative study between Brazil and Portugal
}

\author{
Angela Abreu ${ }^{1 *}$, Rafael T Jomar ${ }^{2}$, Rafaela Costa ${ }^{3}$, Rachel FS Figueiro ${ }^{1}$, Maria Helena N Silva ${ }^{1}$, Pedro Parreira ${ }^{4}$, \\ Teresa Barroso ${ }^{4}$ \\ From INEBRIA 12th Congress, \\ Atlanda, GA, USA. 24-25 September 2015
}

\section{Background}

The consumption of psychoactive substances is a global health problem.

The objectives are to identify the sample sociodemographic profile and use pattern of alcohol, tobacco and cannabis throughout life and in the last three months. Also, to discuss the application of Brief Intervention procedures for problems related to psychoactive substances in patients assisted at the primary health care, in Brazil (Rio de Janeiro) and Portugal (Coimbra).

\section{Material and methods}

The sample included 1700 individuals (Brazil, $\mathrm{n}=1489$; Portugal, $\mathrm{n}=211$ ). All participants filled the instrument Alcohol, Smoking and Substance Involvement Screening Test. Analyses were performed (Student's t-test, ANOVA and Pearson's correlations) using the Statistical Package Social Science (SPSS) version 22.0. A level of statistical significance of 0.05 was established.

\section{Results}

It was observed in both countries higher prevalence in attendance of female participants, married, income between 1 and 2 minimum wage (in Brazil). Considering lifelong use of substances, the Brazilian sample showed $45.5 \%$ of tobacco use, $67.6 \%$ of use of alcoholic beverages and $8.6 \%$ of cannabis use. In Portugal, tobacco (59.3\%), alcoholic beverages $(88.1 \%)$ and cannabis (13.5\%). Considering the daily frequency of use in the last three months in Brazil: tobacco (14.7\%), alcoholic beverages (2.8\%), cannabis (0.7\%); and in Portugal: tobacco (22.7\%),

\footnotetext{
* Correspondence: angelabreu@globo.com

${ }^{1}$ Public Health Nursing, Federal University of Rio de Janeiro, Brazil

Full list of author information is available at the end of the article
}

alcohol (32.7\%) and cannabis (0.5\%). Individuals classified as "moderate risk" were selected to receive Brief Intervention: in Brazil, tobacco use (score 4-26) 16.6\%, alcoholic beverages (score 11-26) 8.8\%, cannabis 1.5\%; Portugal tobacco use (32.0\%), use of alcoholic beverages (19.3\%) and cannabis use (12.7\%).

\section{Conclusions}

It was observed the use of psychoactive substances both countries and the importance of the primary health care in the early detection of health problems associated to the use of those substances. The scenario is responsible for health promoting/protection.

\section{Acknowledgements}

National Counsel of Technological and Scientific Development/ CNPq, Brazil

\section{Authors' details}

'Public Health Nursing, Federal University of Rio de Janeiro, Brazil. ${ }^{2}$ State University of Rio de Janeiro, Brazil. ${ }^{3}$ Federal University of Rio de Janeiro, Brazil. ${ }^{4}$ Coimbra Nursing School, Portugal.

\section{Published: 24 September 2015}

\section{References}

1. World Health Organization (WHO): Global status report on alcohol and health 2014. Genebra : WHO; 2014.

2. Jomar RT, Abreu AMM, Griep RH: Caracterizaíão do consumo de álcool de uma populaía adscrita à estratégia Saúde da Família. Esc Anna Nery 2014, 18(1):96-100.

3. ONU: United Nations Office On Drugs And Crime/Unodc. World Drug Report. United Nations, New York; 2013.

4. Carlini EA, Galduroz JC, Noto AR, Nappo SA: II Levantamento domiciliar sobre o uso de drogas psicotrópicas no Brasil: estudo envolvendo as 108 maiores cidades do país - 2005. Brasilia (DF): Secretaria Nacional Antidrogas; 2007.

5. Ministério da Saúde (BR): Política do Ministério da Saúde para a atenião integral a usuários de álcool e outras drogas. Brasília (DF); 2004. 
6. Babor TH, Higgins-Biddle JC, Saunders JB, Monteiro MG: AUDIT - Teste de identificaíão de problemas relacionados ao uso de álcool: roteiro para uso em ateníão primária. Ribeirão Preto(SP): PAI-PAD; 2008.

doi:10.1186/1940-0640-10-S2-P2

Cite this article as: Abreu et al:: Screening of problems related to alcohol, tobacco and cannabis in primary care settings: a comparative study between Brazil and Portugal. Addiction Science \& Clinical Practice 2015 10(Suppl 2):P2.

Submit your next manuscript to BioMed Central and take full advantage of:

- Convenient online submission

- Thorough peer review

- No space constraints or color figure charges

- Immediate publication on acceptance

- Inclusion in PubMed, CAS, Scopus and Google Scholar

- Research which is freely available for redistribution

Submit your manuscript at www.biomedcentral.com/submit
() Biomed Central 